\title{
Distribution of aluminium fractions in acid forest soils: influence of vegetation changes
}

\author{
Lenka Pavlů, \\ Ondřej Drábek, \\ Šárka Stejskalová, \\ Václav Tejnecký, \\ Monika Hradilová, \\ Antonín Nikodem, \\ Luboš Borůvka
}

\begin{abstract}
This study examines aluminium as a potentially phytotoxic element in acidic forest soils. Concentrations of Al forms in soils are generally controlled by soil chemical conditions, such as $\mathrm{pH}$, organic matter, base cation contents, etc. Moreover, soil conditions are influenced by the vegetation cover. This study analyzed the distribution of Al forms in soils after changes in vegetation. HPLC/IC was used for the separation of three Al fractions in two soil extracts according to their charge. An aqueous extract $\left(\mathrm{Al}_{\mathrm{H} 2 \mathrm{O}}\right)$ simulated the natural soil conditions and bioavailable Al fractions. Potentially available Al form was represented by a $0.5 \mathrm{M} \mathrm{KCl}$ extract $\left(\mathrm{Al}_{\mathrm{KCl}}\right)$. We demonstrated that the vegetation type influences the concentrations of different Al fractions, mainly in the surface organic horizons. Differences were more common in the $\mathrm{KCl}$ extract. The trivalent fraction was less influenced by vegetation changes than the monoand divalent fractions. Afforestation increased the concentrations of $\mathrm{Al}_{\mathrm{KCl}}$ and

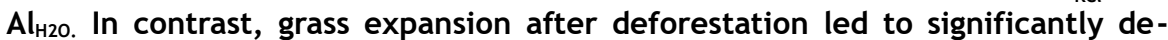
creased concentrations of $\mathrm{Al}_{\mathrm{KCl}}$ and $\mathrm{Al}_{\mathrm{H} 2 \mathrm{O}}$. Concentrations of $\mathrm{Al}_{\mathrm{H} 2 \mathrm{O}}$ in organic horizons were higher in spruce forest than in beech forest. A long-term effect of liming on soil pH and concentrations of potentially toxic Al fractions was not apparent. The results provide information on the variations of Al fractions distributions following vegetation type changes and indicate the existence of some natural mechanisms controlling Al toxicity. Furthermore, the results can be used in the management of forested areas endangered by soil acidification.
\end{abstract}

Keywords: Aluminium Fractionation, Forest Soil, Afforestation, Deforestation, HPLC/IC

\section{Introduction}

Aluminium is one of the more abundant elements in soils, making up approximately $7 \%$ of its inorganic matter (Sposito 1996). Primary and secondary aluminosilicates are the main sources of $\mathrm{Al}$ in soils. Aluminium is mobilized by chemical or biochemical weathering and creates different dissolved ion fractions, which depend on the $\mathrm{pH}$ of the soil solution (Pierzynski et al. 2000). Mineral weathering of aluminosilicates is very slow, but the presence of organic compounds leads to higher weathering rates and to the formation of soluble $\mathrm{Al}$ complexes with organic molecules (Pohlman \& McColl 1988, Van Hees et al. 2001, Fritsch et al. 2009). Therefore, Al occurs in soils and soil waters in many forms or frac- tions. The fractions of dissolved Al determine its potential bioavailability and toxicity. Toxicity to plants decreases qualitatively in the order: $\mathrm{Al}_{13}$ (not in a form of phosphates or silicates), $\mathrm{Al}^{3+}, \mathrm{Al}(\mathrm{OH})^{2+}, \mathrm{Al}(\mathrm{OH})_{2}^{+}$. Aluminium bound with organic complexes has been found to be nontoxic (Sposito 1996). Therefore, the complexation of Al by natural organic ligands is important for regulating concentrations of the highly toxic $\mathrm{Al}^{3+}$ ion in acid soils and natural waters (Wesselink et al. 1996, Collignon et al. 2012).

A significant change in the biogeochemical cycling of Al has resulted from the manmade acidification of the environment (Exley 2003). Past extensive acid deposition (Kopáček \& Vesely 2005) of strong acids
The Czech University of Life Sciences Prague, Department of Soil Science and Soil Protection, Kamýcká 129, 16500 Prague Suchdol (Czech Republic)

@ Lenka Pavlů (pavlu@af.czu.cz)

Received: May 23, 2017 - Accepted: Aug 27, 2018

Citation: Pavlů L, Drábek O, Stejskalová Š, Tejnecký V, Hradilová M, Nikodem A, Borůvka L (2018). Distribution of aluminium fractions in acid forest soils: influence of vegetation changes. iForest 11: 721-727. - doi: 10.3832/ifor2498-011 [online 2018-11-06]

Communicated by: Giustino Tonon (sulfuric or nitric), has accelerated the release of Al from aluminosilicates and secondary Al soil phases. Higher sulfate content affects soil acidity and transforms hydroxylated $\mathrm{Al}$ fractions to $\mathrm{Al}^{3+}$ (Norton \& Vesely 2003, Shaw \& Hendry 2009, Jones et al. 2011). A strong negative correlation between the concentration of exchangeable $\mathrm{Al}$ in soils and the level of $\mathrm{SO}_{4}{ }^{2-}$ deposition in the $\mathrm{O}$ horizon were demonstrated by Lawrence et al. (2015). Additionally, strong acid anions increase the release of Al-organic complexes in spodic soil horizons (Zeysset et al. 1999). Soil waters of anthropogenically acidified areas thus have a higher content of ionic and toxic Al forms. This situation is typical of the northern parts of the Czech Republic (Sucharova et al. 2011). Mountainous forests in the top parts of the mountains were damaged directly by acid rain and $\mathrm{SO}_{2}$ fumigation in the past. Large-scale forest dieback, followed by grass expansion, has occurred. Damage to soils by anthropogenic acidification is related to a low content of base cations, a very acidic character of soils, and abundant mobile Al forms (Borg \& Sundbom 2014). These conditions have made forest recovery difficult, including at present. Amelioration by forest liming has been attempted in these areas. Our previous studies (Mládková et al. 2004, Boruvka et al. 2005) reported that the distribution of 
Al forms in soils is controlled by $\mathrm{pH}$. The $\mathrm{pH}$ value can be conditioned by the natural presence of $\mathrm{Ca}$ or $\mathrm{Mg}$ carbonate minerals, or it can be regulated by adding limestone. Organic matter plays a role in Al distribution by providing sorption and binding sites (Norton \& Vesely 2003).

At altitudes below approximately $800 \mathrm{~m}$ a.s.l., natural forest cover in the Czech Republic consists of beech (Fagus sylvatica L.) or mixed beech-spruce (Picea abies [L.] Karst.) forests. In the past, these natural forests were widely transformed into spruce monocultures, which also can accelerate acidification processes (Augusto et al. 2002, De Schrijver et al. 2007).

Many combinations of effects exist in the natural soil environment, and the final $\mathrm{Al}$ distribution is controlled by many factors. Drábek et al. (2003) and Brandtberg \& Simonsson (2003) showed marked differences in Al fractions distribution among soils of cropland, grassland, and forest, and also between different forest types. The aim of this research is to study the relationships between the dissolved or potentially soluble Al fraction distribution and landuse changes (afforestation, deforestation, amelioration). The main hypothesis is that land-use change impacts the Al fraction distribution in soil. The second hypothesis is that the effect of acid soil amelioration results in a long-term decrease of dissolved Al concentrations in soil.

\section{Methods}

This paper reports findings from three separate projects on aluminium fractionation in soils. These projects were located in two mountainous areas in the north of the Czech Republic (Fig. 1), where soil acidification has been observed and studied (Drábek et al. 2007, Dlouhá et al. 2009, Bradová et al. 2015). The altitude of the Jizera Mountains ranges between 400 and 1100 $\mathrm{m}$ a.s.l., and the altitude of Giant Mountains ranges between 400 and $1600 \mathrm{~m}$. In both areas, the average annual precipitation is between 1200 and $1300 \mathrm{~mm}$, and the average annual temperature is $4-7^{\circ} \mathrm{C}$. Precipitation and temperature are naturally altitude-dependent. The Jizera Mts. are underlaid by homogenous granite, while the Giant Mts. geology is more variable. At higher elevation, the bedrock is of the same granite massif as in the Jizera Mts. At lower elevation, the bedrock consists of gneiss, schist, and phyllites.

The afforestation study (1) in the Giant Mts. (Fig. 1) focused on the comparison among meadow, afforested meadow (50year-old Norway spruce, and an old-growth Norway spruce forest. All sampling areas are on gneiss bedrock, and single variants are in close vicinity. In each vegetation cover variant, soil pits were dug $(4,4$, and 3 , respectively), and soil samples were collected (described in detail by Dlouhá et al. 2009).

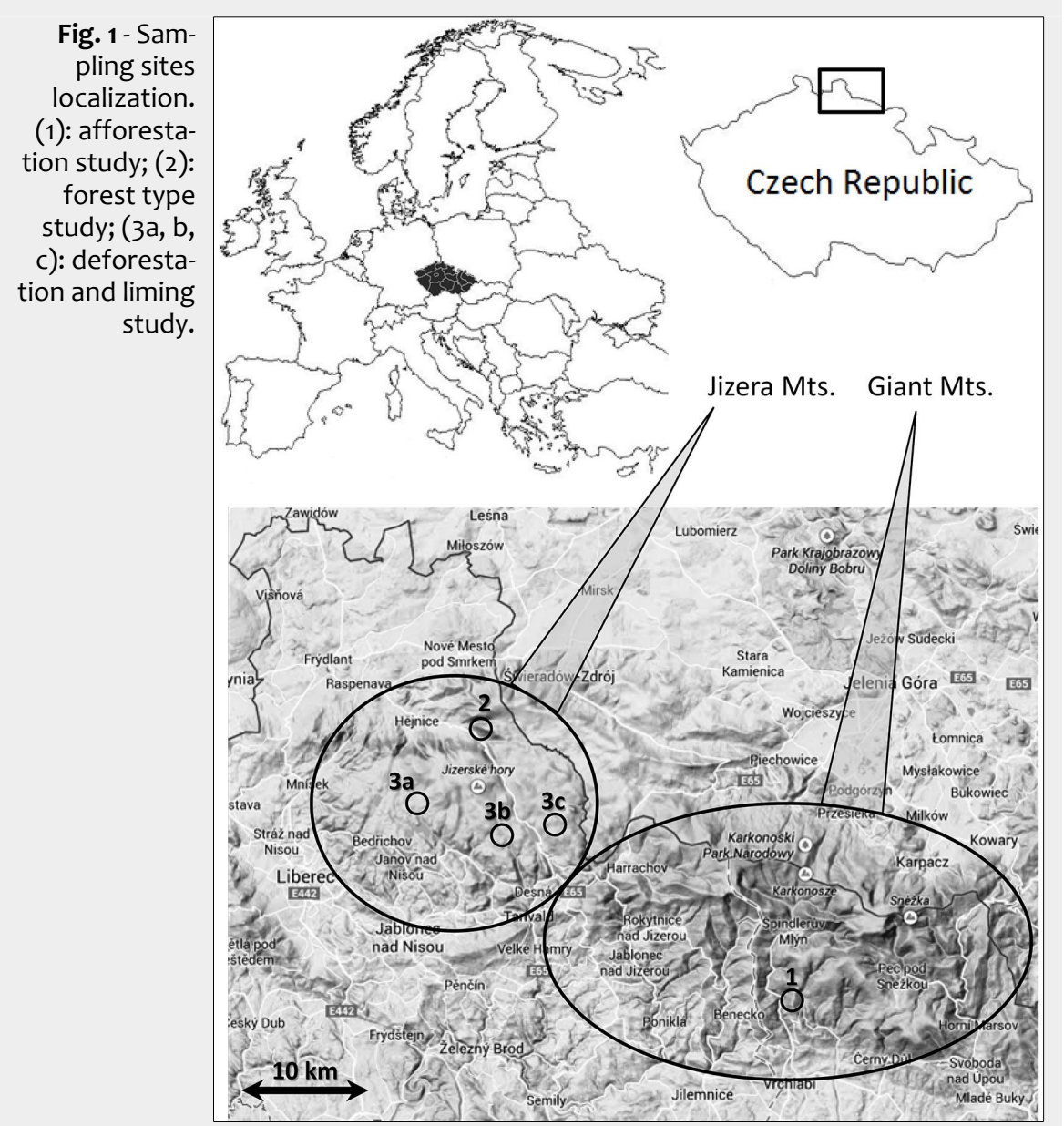

The study on forest type change (2) obtained results from two long-term monitoring plots in the Jizera Mts. (630-680 $\mathrm{m}$ a.s.l. - Fig. 1), described in detail by Bradová et al. 2015. The first plot is covered by an oldgrowth beech forest, typical for that location, and the second one is covered by a 100-year-old Norway spruce forest, which had artificially replaced a beech forest. Sampling occurred monthly from April to October during the years 2008-2011 (three soil pits per forest type in each month).

The deforestation and amelioration study (3) was conducted in the higher parts of the Jizera Mts. (800-900 m a.s.l. - Fig. 1), where the forest died in the 1980s due to acid rain, and the resulting change in the lighting conditions led to the expansion of the grass. For several decades, a large area was covered by grasses (Calamagrostis villosa [Chaix] J. F. Gmel., Deschampsia flexuosa [L.] Drejer) and was difficult to reforest. Liming was used to counter the effects of soil acidification from acid rain. Our study compared soil conditions of the soils still covered by grass (control), those covered by grass with amelioration by dolomitic limestone (once, $2 \mathrm{t} \mathrm{ha}^{-1}$ ) 25 years before sample collection (limed), and those covered by more than 40-year-old Norway spruce native forest (forest). Results represent the analysis of 9 soil pits in each variant ( 3 isolated plots $-3 a, b$, and c in Fig. 1), where all 3 variants are in close proximity and sampled by 3 soil pits each.

Soil sampling was very similar in all studies. Soil pits, approximately $50 \times 50 \mathrm{~cm}$, were excavated for soil description and sample collection. Soils were classified by IUSS Working Group (2015), mostly as Cambisols or Podzols. Samples from all sufficiently thick horizons were collected. In most cases, surface organic horizons (F: fermentation horizons; $\mathrm{H}$ : humified horizons), organomineral humic horizons (A), eluvial albic horizons (Ep), spodic horizons (Bspod), cambic horizons (Bv), and substrate horizons (C) were present. Samples were air dried and sieved to $<2 \mathrm{~mm}$, and basic soil characteristics were determined. Active and exchangeable $\mathrm{pH}\left(\mathrm{pH}_{\mathrm{H}_{2} \mathrm{O}}\right.$ and $\mathrm{pH}_{\mathrm{KCl}}$, respectively) were determined potentiometrically by ion-selective electrode. $\mathrm{Ca}\left(\mathrm{Ca}_{\mathrm{AR}}\right)$ and $\mathrm{Mg}\left(\mathrm{Mg}_{\mathrm{AR}}\right)$ were determined after soil digestion with aqua regia by atomic absorption spectroscopy (AAS Varian SpectrAA-200 ${ }^{\oplus}$, VARIAN, Australia). Effective cation exchange capacity (eCEC) of mineral horizons was determined by the Mehlich method with unbuffered $0.1 \mathrm{M}$ $\mathrm{BaCl}_{2}$ extraction solution (Podlešáková et al. 1992). Cation exchange capacity (CEC) was determined by the Bower method, with $\mathrm{Na}^{+}$as an index ion (Heese 1998); $\mathrm{Na}$ in the extract solution was determined by AAS.

A method of $\mathrm{Al}$ fractionation in deionized water and $0.5 \mathrm{M} \mathrm{KCl}$ extract by $\mathrm{HPLC} / \mathrm{IC}$ was used (Drábek et al. 2005). This method enables $\mathrm{Al}$ fractions to be separated into three different groups according to their 
charge: $\mathrm{Al}(\mathrm{X})^{1+}\left[\right.$ i.e., $\mathrm{Al}(\mathrm{OH})_{2}{ }^{+}, \mathrm{Al}\left(\mathrm{SO}_{4}\right)^{+}, \mathrm{AlF}_{2}{ }^{+}$, $\mathrm{Al}\left(\right.$ oxalate) ${ }^{+}, \mathrm{Al}\left(\mathrm{H}\right.$-citrate) ${ }^{+}$, etc. $] ; \mathrm{Al}(\mathrm{Y})^{2+}$ $\left[\mathrm{Al}(\mathrm{OH})^{2+},(\mathrm{AlF})^{2+}\right.$, etc. $]$; and $\mathrm{Al}^{3+}\left(\mathrm{Al}^{3+}\right.$ and transformed hydroxyl Al polymers). However, $\mathrm{Al}(\mathrm{X})^{1+}$ fractions co-elute with $\mathrm{Al}(\mathrm{Z})^{\leq 0}$ fractions, where $Z$ represents mainly organic ligands. The sum of the fractions in aqueous extracts is designated $\mathrm{Al}_{\mathrm{H} 2 \mathrm{O}}$, and that of the $\mathrm{KCl}$ extracts is $\mathrm{Al}_{\mathrm{KCl}}$. A modified methodology of $\mathrm{Al}$ fractionation was used in the study on forest type change (2). This study also focused on the distribution of dissolved organic carbon (DOC - Tejnecký et al. 2010), and the sample processing was adjusted to apply to DOC measurements (Jones \& Willett 2006). Fresh, unsieved soil samples were used, and only the aqueous extract was analyzed. Therefore, the concentrations of all studied Al fractions are lower than those from the other studies.

Statistical analysis, one-way analysis of variance, $t$-test, and paired $t$-test were performed using STATISTICA ${ }^{\circledast}$ v. 9.1 software (StatSoft Inc., Tulsa, OK, USA).

\section{Results}

All presented graphs (Figs. 2 to 5) show that $\mathrm{KCl}$ extracts had approximately 10 times more $\mathrm{Al}$ than deionized water. The relative distribution of the studied fractions also differs between extracts. The dominant fraction in $\mathrm{KCl}$ is $\mathrm{Al}^{3+}$ and in the water extract it is $\mathrm{Al}(\mathrm{X})^{1+}$.

Generally, all presented studies were located in mountainous areas with acidic bedrock, representing areas strongly affected by soil acidification. The prevailing soil types in these areas are dystric Cambisols in the lower parts, and Podzols in the upper parts of the mountains. The differences in Al fraction distribution in the soil profiles of both these soil types are presented in Fig. 2 and Tab. S1 (Supplementary material).

\section{Afforestation effect}

Basic soil characteristics of meadow, young (50 years old) forest on former meadow, and native forest soils are shown in Tab. 1. There are clear differences among these three plots according to the described soil type. Cambisol was found in the meadow and young forest plots, whereas, on the original forest plot, Podzol with very well-defined diagnostic horizons was recognized. The strong-acid character of forest soil compared to other plots is also apparent. Cation exchange capacity is generally associated with organic matter in soils, and it decreases from organic to mineral soil horizons. Spodic horizons are enriched by organic compounds, and CEC follows this trend. The statistical comparison of vegetation cover variants in the sampled soil horizons is shown in Tab. 2.

The results of $\mathrm{Al}$ fractionation are shown in Fig. 3 and Tab. 2. Concentrations of $\mathrm{Al}(\mathrm{X})^{1+}$ and $\mathrm{Al}^{3+}$ in the $\mathrm{A}$ horizon in both extracts are significantly higher for the 50year-old forest soil than for the meadow. Concentrations of all $\mathrm{Al}$ fractions in aque-

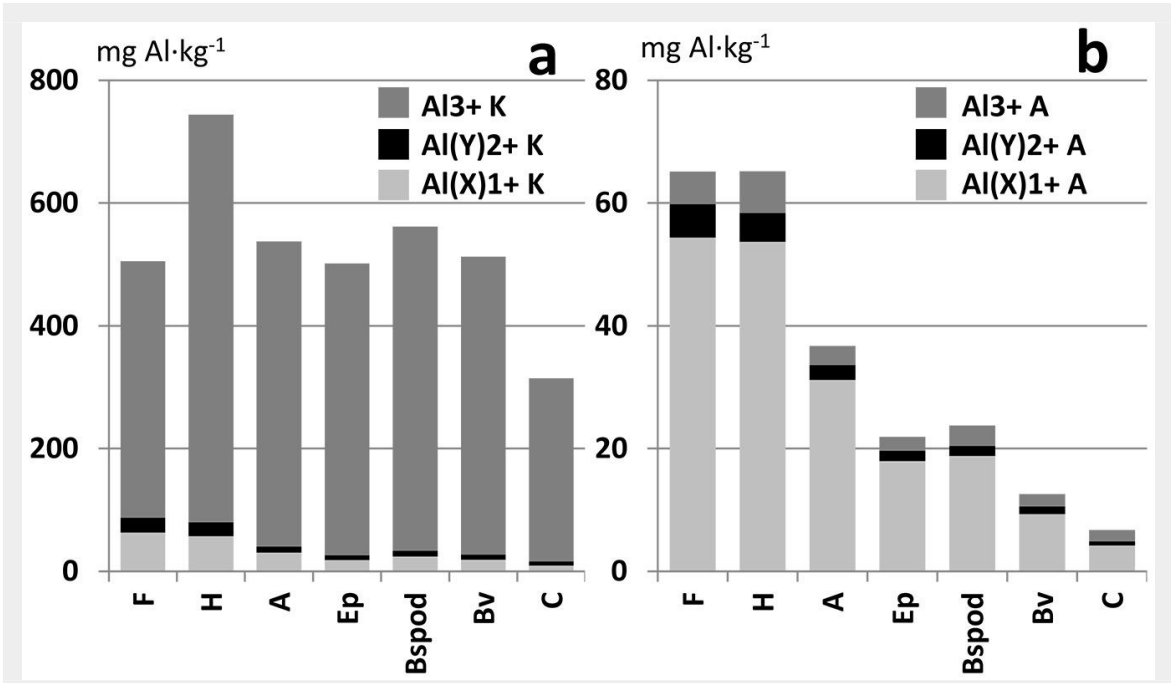

Fig. 2 - Distribution of $\mathrm{Al}$ fractions in soil horizons (a) in $\mathrm{KCl}$ extract, and (b) in aqueous extract). Average values of all samples from Jizera Mts. and Giant Mts.

ous extract are higher in the mineral $\mathrm{Bv}$ forest in the $\mathrm{F}$ horizon. The opposite trend horizon of forest soil than in the meadow. was observed in the aqueous extract.

The highest amount of phytotoxic $\mathrm{Al}^{3+}$ in

both extracts occurred in the spodic hori- Forest type change

zons. Concentrations of $\mathrm{Al}$ fractions in the Tab. 3 shows the values of soil $\mathrm{pH}$ in the $\mathrm{KCl}$ extract increased from young to old original beech forest and in the planted

Tab. 1 - Average values of basic soil characteristics for separate soil horizons. $(M)$ : scythed meadow in forest vicinity; (F 50): 50 years old forest planted on former meadow; (F): old growth forest.

\begin{tabular}{lllccc}
\hline Variant & Soil type & Horizon & $\mathrm{pH}_{\mathrm{H} 2 \mathrm{O}}$ & $\mathrm{pH}_{\mathrm{KCl}}$ & $\begin{array}{c}\mathrm{CEC} \\
\left(\mathbf{m m o l ~ 1 0 0 ~ ~ ^ { - 1 }}\right)\end{array}$ \\
\hline M & cambisol & $\mathrm{A}$ & 4.79 & 3.38 & 26.13 \\
& & $\mathrm{BV}$ & 4.90 & 3.56 & 18.06 \\
\hline F50 & cambisol & $\mathrm{F}$ & 3.80 & 2.79 & 50.38 \\
& & $\mathrm{~A}$ & 3.83 & 2.91 & 24.13 \\
& & $\mathrm{BV}$ & 4.16 & 3.23 & 16.81 \\
\hline F & podzol & $\mathrm{F}$ & 3.17 & 2.05 & 140.83 \\
& & $\mathrm{H}$ & 3.11 & 2.01 & 92.00 \\
& & Ep & 3.53 & 2.35 & 8.58 \\
& & Bspod & 3.68 & 3.04 & 47.07 \\
\hline
\end{tabular}

Tab. 2 - Results of $t$-test ( $t$-values of the differences) comparing the distribution of basic soil characteristics and $\mathrm{Al}$ fractions (K: in $\mathrm{KCl}$ extract; $\mathrm{A}$ : in aqueous extract) in selected soil horizons of three vegetation cover types. $(M)$ : scythed meadow in forest vicinity; (F50): 50-year-old forest planted on former meadow; (F): old growth forest.

\begin{tabular}{|c|c|c|c|c|c|c|}
\hline \multirow[t]{2}{*}{ Variable } & \multicolumn{2}{|c|}{$\begin{array}{l}\text { F horizon } \\
(\text { F50 × F) }\end{array}$} & \multicolumn{2}{|c|}{$\begin{array}{l}\text { A horizon } \\
(M \times F 50)\end{array}$} & \multicolumn{2}{|c|}{$\begin{array}{l}\text { Bv horizon } \\
(M \times F 50)\end{array}$} \\
\hline & $t$ & Prob & $t$ & Prob & $t$ & Prob \\
\hline $\mathrm{pH}_{\mathrm{H} 2 \mathrm{O}}$ & 8.13 & $<0.001$ & 6.87 & 0.001 & 3.55 & 0.012 \\
\hline $\mathrm{pH}_{\mathrm{KCl}}$ & 8.90 & $<0.001$ & 5.76 & $<0.001$ & 2.43 & 0.051 \\
\hline CEC & -4.23 & 0.008 & 1.77 & 0.128 & 0.77 & 0.473 \\
\hline $\operatorname{Al}(X)^{1+} \mathrm{K}$ & -4.72 & 0.005 & -9.40 & 0.003 & -2.76 & 0.070 \\
\hline $\mathrm{Al}(\mathrm{Y})^{2+} \mathrm{K}$ & -4.77 & 0.005 & 1.46 & 0.240 & -0.95 & 0.413 \\
\hline $\mathrm{Al}^{3+} \mathrm{K}$ & -2.02 & 0.090 & -4.09 & 0.026 & -1.42 & 0.251 \\
\hline $\mathrm{Al}_{\mathrm{KCl}}$ & -2.30 & 0.070 & -4.19 & 0.025 & -1.50 & 0.231 \\
\hline $\mathrm{Al}(\mathrm{X})^{1+\mathrm{A}}$ & 2.69 & 0.043 & -6.70 & 0.007 & -3.08 & 0.054 \\
\hline $\mathrm{Al}(\mathrm{Y})^{2+} \mathrm{A}$ & 0.29 & 0.781 & -2.50 & 0.087 & -4.42 & 0.022 \\
\hline $\mathrm{Al}^{3+} \mathrm{A}$ & 0.65 & 0.544 & -5.37 & 0.013 & -2.79 & 0.068 \\
\hline $\mathrm{Al}_{\mathrm{H} 2 \mathrm{O}}$ & 2.36 & 0.065 & -6.73 & 0.007 & -3.57 & 0.038 \\
\hline
\end{tabular}



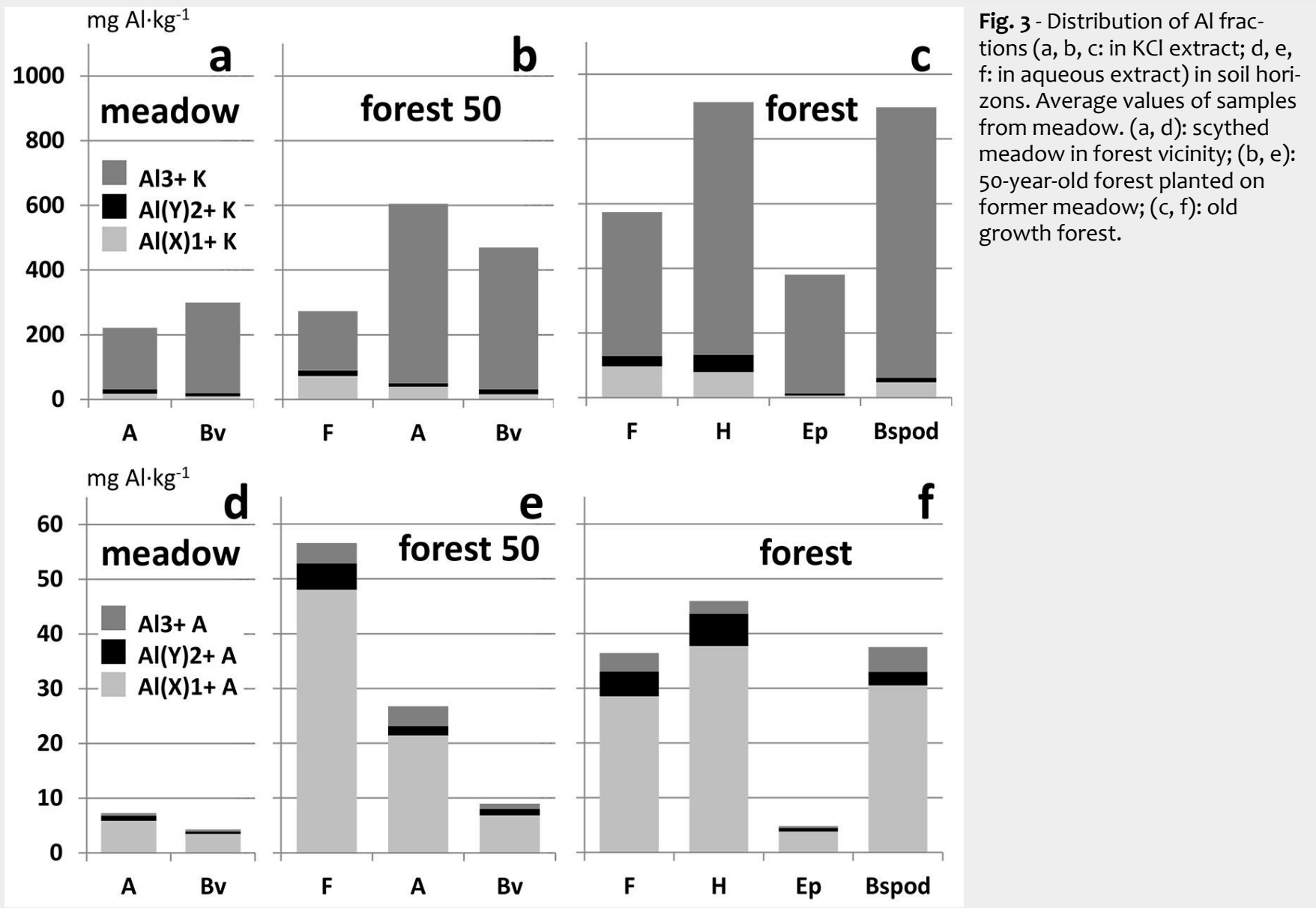

Tab. 3 - Average values of $\mathrm{pH}_{\mathrm{H}_{2} \mathrm{O}}$ and $\mathrm{pH}_{\mathrm{Kcl}}$ in beech and spruce forest, by soil horizons.

\begin{tabular}{|c|c|c|c|c|}
\hline \multirow{2}{*}{ 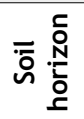 } & \multicolumn{2}{|c|}{ Beech forest } & \multicolumn{2}{|c|}{ Spruce forest } \\
\hline & $\mathrm{pH}_{\mathrm{H} 2 \mathrm{O}}$ & $\mathrm{pH}_{\mathrm{kCl}}$ & $\mathrm{pH}_{\mathrm{H} 2 \mathrm{O}}$ & $\mathrm{pH}_{\mathrm{kCl}}$ \\
\hline $\mathrm{F}$ & 4.18 & 3.33 & 3.84 & 2.87 \\
\hline $\mathrm{H}$ & 4.14 & 3.5 & 3.78 & 2.96 \\
\hline A & 4.17 & 3.58 & 3.89 & 3.19 \\
\hline B & 4.27 & 3.78 & 4.11 & 3.77 \\
\hline
\end{tabular}

Tab. 4 - Differences in the distribution of $\mathrm{pH}$ and $\mathrm{Al}$ fractions between beech and spruce forests for each soil horizon (results of pair $t$-test; $t$-values of the differences).

\begin{tabular}{lcccccccr}
\multirow{2}{*}{ Variable } & \multicolumn{2}{c}{ F horizon } & \multicolumn{2}{c}{ H horizon } & \multicolumn{2}{c}{ A horizon } & \multicolumn{2}{c}{ B horizon } \\
\cline { 2 - 9 } & \multicolumn{1}{c}{$\boldsymbol{t}$} & \multicolumn{1}{c}{ Prob } & \multicolumn{1}{c}{$\boldsymbol{t}$} & \multicolumn{1}{c}{ Prob } & \multicolumn{1}{c}{$\boldsymbol{t}$} & \multicolumn{1}{c}{ Prob } & \multicolumn{1}{c}{$\boldsymbol{t}$} & \multicolumn{1}{c}{ Prob } \\
\hline $\mathrm{pH}_{\mathrm{H} 2 \mathrm{O}}$ & 10.97 & $<0.001$ & 14.24 & $<0.001$ & 7.67 & $<0.001$ & 5.30 & $<0.001$ \\
$\mathrm{pH}_{\mathrm{KCl}}$ & 17.47 & $<0.001$ & 23.80 & $<0.001$ & 9.03 & $<0.001$ & 1.25 & 0.218 \\
$\mathrm{Al}(\mathrm{X})^{1+} \mathrm{A}$ & -0.23 & 0.818 & -6.13 & $<0.001$ & -3.11 & 0.006 & -3.20 & 0.003 \\
$\left.\mathrm{Al}^{\mathrm{Y}}\right)^{2+} \mathrm{A}$ & -1.12 & 0.273 & -2.69 & 0.012 & -2.12 & 0.047 & -3.32 & 0.003 \\
$\mathrm{Al}^{3+} \mathrm{A}$ & 3.12 & 0.004 & 1.29 & 0.207 & -0.83 & 0.417 & -2.50 & 0.018 \\
$\mathrm{Al}_{\mathrm{H} 2 \mathrm{O}}$ & 1.28 & 0.211 & -3.76 & $<0.001$ & -2.75 & 0.013 & -4.20 & $<0.001$ \\
\hline
\end{tabular}
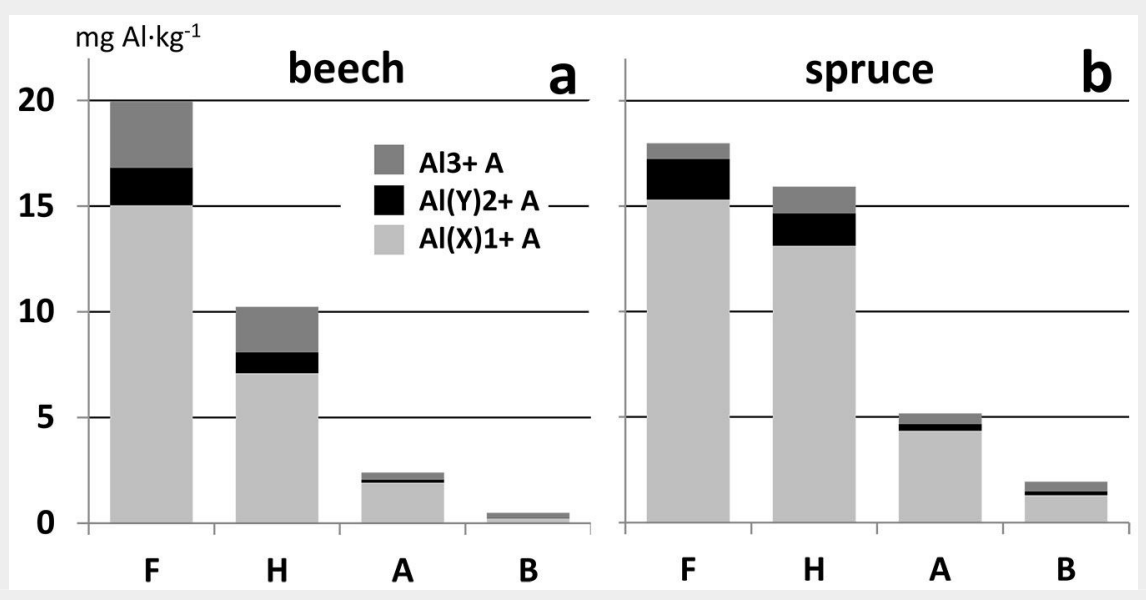

Fig. 4 - Distribution of Al fractions in aqueous extract in soil horizons. Average values of samples from beech (a) and spruce (b) forest. spruce forest. A higher $\mathrm{pH}$ of surface horizons in the beech forest is evident, in comparison with spruce forest. Statistical differences are presented in Tab. 4.

Results of Al fractionation (Fig. 4, Tab. 4) show that the differences between beech and spruce forest soil exist in both organic and mineral horizons. Except for the $\mathrm{F}$ horizon, the sum of the Al fractions, and also $\mathrm{Al}(\mathrm{X})^{1+}$ and $\mathrm{Al}(\mathrm{Y})^{2+}$ fractions concentrations, are significantly higher in the spruce forest. The concentration of the $\mathrm{Al}^{3+}$ fraction in the organic $\mathrm{F}$ horizon is higher in the beech forest than in the spruce forest.

\section{Deforestation and amelioration}

The basic soil characteristics of long-term deforested area (grass-limed, grass-control) and surviving native forest plots are presented in Tab. 5. Analysis of variance (Tab. S2 in Supplementary material) shows 
that organic horizons are more affected than mineral horizons by land-use change. Forested soils are more acidic than grasscovered soils. The long-term liming effect resulted in higher $\mathrm{Ca}_{A R}$ concentrations in the organic horizons of the limed variant. Soil $\mathrm{pH}$ was not significantly changed 25 years after liming. Higher differences in soil $\mathrm{pH}$ were found between forest and grasscovered (control and limed) plots. Cation exchange capacity was similar for all land uses.

The results of $\mathrm{Al}$ fractionation and comparison of vegetation cover variants are shown in Fig. 5 and Tab. S2 (Supplementary material). Analysis of variance for the Al fractions showed that most of the differences occur in the surface organic horizons. These horizons in the surviving forest have the highest concentrations of most of the Al fractions. Almost no difference between the limed and control variant was found. A change of land use influenced the $\mathrm{Al}(\mathrm{X})^{1+}$ and $\mathrm{Al}(\mathrm{Y})^{2+}$ fraction distribution more than that of $\mathrm{Al}^{3+}$.

\section{Discussion}

Firstly, the differences between Al distributions in the dominant soil types in this mountain area (Fig. 2, Tab. S1) are addressed. Podzol formation is directly controlled by Al transport in the soil profile, from the Ep horizon to spodic type horizons with or without organic matter (Lundström et al. 2000, Sauer et al. 2007). Relative Al depletion of the Ep horizon and rela-
Tab. 5 - Average values of basic soil characteristics in variants (grass-limed, grass-control, native forest) separately for soil horizons.

\begin{tabular}{llllccc}
\hline Variant & Horizon & $\mathrm{pH}_{\mathrm{H} 20}$ & $\mathrm{pH}_{\mathrm{KCl}}$ & $\begin{array}{c}\mathbf{M g}_{\mathrm{AR}} \\
\left(\mathbf{M g ~ k g}^{-1}\right)\end{array}$ & $\begin{array}{c}\mathrm{Ca}_{\mathrm{AR}} \\
\left(\mathbf{m g}^{-1} \mathbf{k g}^{-1}\right)\end{array}$ & $\begin{array}{c}\mathrm{ECEC} \\
\left(\mathbf{m m o l ~ 1 0 0 g ^ { - 1 }}\right)\end{array}$ \\
\hline Grass & $\mathrm{F}$ & 4.33 & 3.57 & 1396 & 2282 & 26.75 \\
limed & $\mathrm{H}$ & 4.11 & 3.26 & 813 & 1292 & 22.90 \\
& Ep & 4.05 & 3.32 & 683 & 246 & 7.01 \\
& Bspod & 4.21 & 3.78 & 2794 & 376 & 8.01 \\
& $\mathrm{C}$ & 4.51 & 4.23 & 3634 & 429 & 3.34 \\
Grass & $\mathrm{F}$ & 4.23 & 3.45 & 1034 & 986 & 24.14 \\
control & $\mathrm{H}$ & 4.13 & 3.40 & 861 & 545 & 22.97 \\
& Ep & 4.12 & 3.49 & 1353 & 332 & 7.76 \\
& Bspod & 4.18 & 3.65 & 2692 & 372 & 10.65 \\
& $\mathrm{C}$ & 4.44 & 4.19 & 4042 & 470 & 3.44 \\
Native & $\mathrm{F}$ & 3.88 & 2.96 & 929 & 1408 & 24.75 \\
forest & $\mathrm{H}$ & 3.82 & 2.96 & 523 & 422 & 25.24 \\
& Ep & 3.70 & 3.28 & 1105 & 206 & 7.20 \\
& Bspod & 4.08 & 3.74 & 2895 & 299 & 8.74 \\
& $\mathrm{C}$ & 4.29 & 4.18 & 4295 & 447 & 3.84 \\
\hline
\end{tabular}

tive $\mathrm{Al}$ enrichment of the Bspod horizon tively enriched with $\mathrm{Al}$ in contrast to subcan be seen in Fig. 2. The high contents of strate (C), but aluminium content is still all $\mathrm{Al}$ fractions in the surface organic hori- lower than in the Bspod horizon, which is zons are probably due to the high sorption enriched with Al transported from the upcapacity of organic compounds and long- per horizons (Fig. 2, Tab. S1). Different Al term accumulation of organic matter, espe- distributions in the Podzol and Cambisol cially in the $\mathrm{H}$ horizon (Niemtur et al. 2002). soil profiles were also shown by Berggren The cambic Bv horizon is characterized by (1992) and Maitat et al. (2000). These difbraunification processes. Fe and $\mathrm{Al}$ are re- ferences illustrate the importance of the leased from silicates in situ by this special study sites comparison according to soil type of weathering. The Bv horizon is rela- horizon.
Fig. 5 - Distribution of Al fractions (a, b, c: in $\mathrm{KCl}$ extract; d, e, $\mathrm{f:}$ in aqueous extract) in soil horizons. Average values of samples from grass-limed (a, d), grasscontrol (b, e), and native forest $(c, f)$.
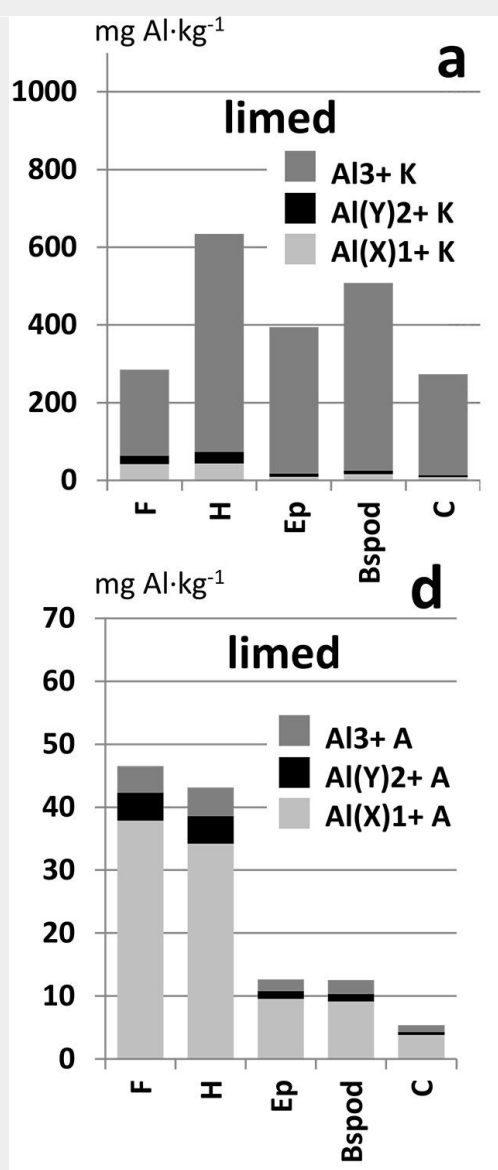
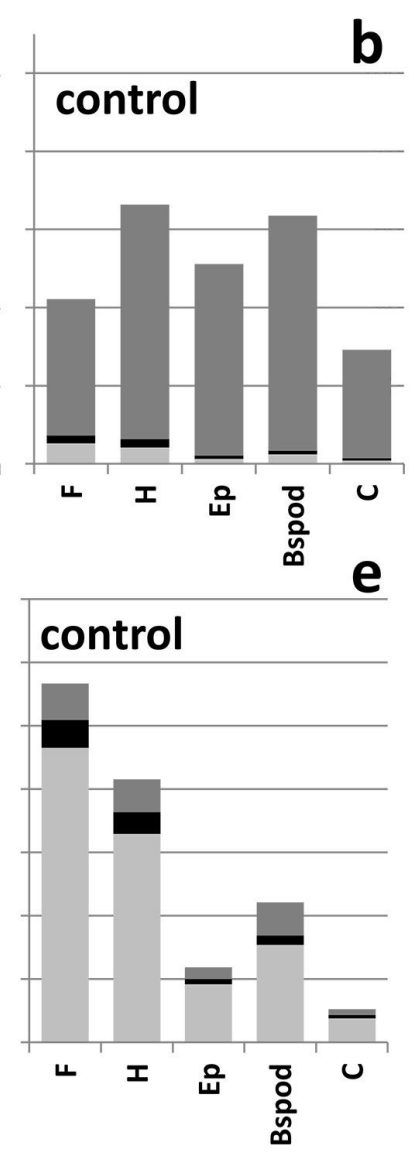

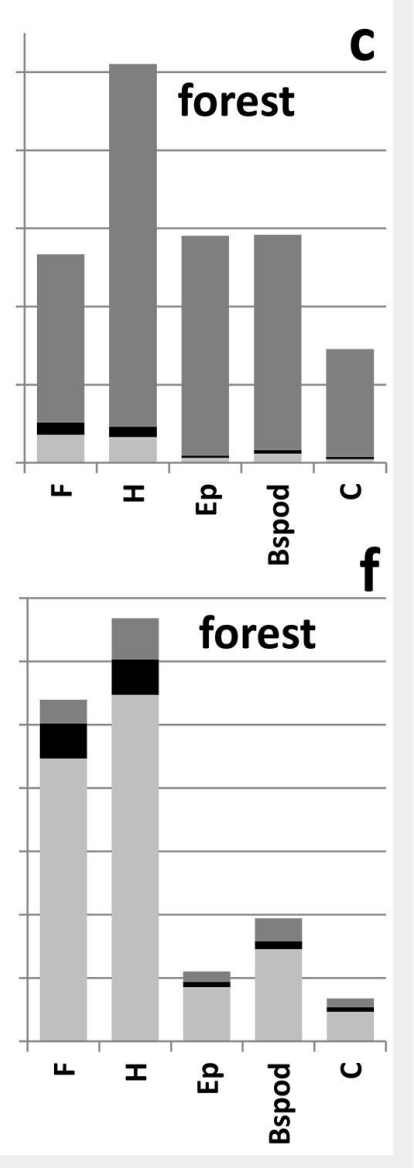




\section{Afforestation effect}

Generally, long-term planting of spruce or other coniferous species leads to enhanced soil acidification and conditions conducive to the podzolization process (Brady \& Weil 2008). Findings in line with this theory are documented in Tab. 1, which shows that the Podzol soil type was found only in oldgrowth forest. The increase of soil acidity leads to Al release in its mobile forms (Sposito 1996, Pierzynski et al. 2000). The results in Fig. 3 and Tab. 2 confirm that the afforestation of meadow leads to the release of monovalent and trivalent Al fractions, especially in the A horizon. A similar situation was documented by Adams et al. (2001) in New Zealand.

The concentration of monovalent and divalent $\mathrm{Al}$ fractions in the $\mathrm{KCl}$ extract increased significantly from young to old forest in the $\mathrm{F}$ horizon (Fig. 3, Tab. 2). This agrees with the soil $\mathrm{pH}$ decrease and cation exchange capacity increase (Drábek et al. 2005 - Tab. 1, Tab. 2). The opposite trend was seen in the aqueous extract. The concentration of the monovalent Al fraction decreased from young to old forest in the $\mathrm{F}$ horizon. This result may be explained by the difference between the aggrading humus layers of young forest and the mature humus layers of old forests. It has been suggested that leaf litter quality varies with tree age and has a huge impact on humus development (Inagaki et al. 2004, Descheemaeker et al. 2009). Ponge et al. (1998) suggested that a higher uptake of nutrients by trees during their phase of intense growth may lead to lower soil nutrient availability and decomposer activities. The decrease in biological activity may lead to lower litter decay rates, promoting the accumulation of organic materials (Trap et al. 2011). The aggrading humus layers of young forest have lower cation exchange capacity and do not bind $\mathrm{Al}$ as much as the mature humus layers in old forests.

Other authors (Drábek et al. 2003) found a huge difference in the relative distribution of $\mathrm{Al}$ fractions in $\mathrm{KCl}$ extracts between spruce and meadow. This was not confirmed in the present study.

\section{Forest type change}

Better soil conditions ( $\mathrm{pH}$, nutrient concentrations) of beech than spruce forest have been reported by several authors (Misson et al. 2001, Niemtur et al. 2002). The organic horizons of Norway spruce forest were found to be more acidic than those of beech forest (Tab. 3, Tab. 4). It could be supposed that higher concentrations of Al fractions will be found in spruce forest. The indirect relationship between the concentration of mobile Al forms and soil reaction is well known (Sposito 1996, Pierzynski et al. 2000). However, the results in Fig. 4 and Tab. 4 confirm this only partially. In the case of the $\mathrm{F}$ horizon and $\mathrm{Al}^{3+}$ fraction, the opposite trend was found. Tejnecký et al. (2010) showed higher dis- solved organic carbon (DOC) content in spruce forest surface horizons than in beech forest. DOC is a significant ligand for Al complexation (Van Hees et al. 2000). These two facts have opposing effects on $\mathrm{Al}^{3^{+}}$concentration ( $\mathrm{Li} \&$ Johnson 2016). It is probable that the DOC effect plays a more important role than soil $\mathrm{pH}$. Therefore, Al complexation with DOC would decrease $\mathrm{Al}^{3+}$ concentration in spruce more than it would in beech forest soils.

\section{Deforestation and amelioration}

Analysis of variance (Fig. 5, Tab. S2) for Al fractions showed that most of the differences occur in the surface organic horizons. Twenty-five years after limestone application, the difference between grasslimed and grass-control was not found. This result is not in contradiction with the decrease of Al concentration related to the short-time liming effect (Tyler \& Olsson 2001, Boruvka et al. 2007 Huang et al. 2014). In contrast, both of these grass variants often have lower concentrations of Al fractions in comparison with native forest. Therefore, grass expansion could be considered as a natural regeneration mechanism of acidified soils. However, the toxic effect of aluminium, represented by $\mathrm{Al}^{3+}$ concentration in aqueous extract, is similar in all variants. Only the potential $(\mathrm{KCl}$ extract) risk of Al toxicity was higher in the native forest variant.

\section{Conclusion}

Vegetation cover change can influence the concentration of Al fractions, mainly in surface organic horizons. Differences were found to be more common in the $\mathrm{KCl}$ extracts and for $\mathrm{Al}(\mathrm{X})^{1+}$ and $\mathrm{Al}(\mathrm{X})^{2+}$ fractions than in aqueous extracts and the $\mathrm{Al}^{3+}$ fraction, respectively. Afforestation increased the concentration of $\mathrm{Al}_{\mathrm{KCl}}$ and $\mathrm{Al}_{\mathrm{H}_{2} \mathrm{O}}$. An increase of $\mathrm{Al}$ fraction concentrations in the $\mathrm{KCl}$ extract from younger to older forests was observed in the $\mathrm{F}$ horizon. The opposite trend occurred in the aqueous extract. This could be explained by the fact that while forming the humus layer, Al is not bound as strongly as in the mature humus layer of old-growth spruce forests. Where natural beech forest was replaced by spruce, the concentration of $\mathrm{Al}_{\mathrm{H}_{2} \mathrm{O}}$ increased, but concentration of $\mathrm{Al}^{3+}$ decreased in the $\mathrm{F}$ horizon. This seems to confirm that organic compounds in the soils of spruce forest can transform this toxic fraction. In contrast, grass expansion after deforestation led to a significant decrease in the concentrations of $\mathrm{Al}_{\mathrm{KCl}}$ and $\mathrm{Al}_{\mathrm{H} 2 \mathrm{O}}$. Acid soil liming increased the $\mathrm{Ca}$ concentration, but their long-term effects on soil $\mathrm{pH}$ and the concentrations of potentially toxic Al fractions were not apparent. With respect to the distribution of the most toxic Al fraction $\left(\mathrm{Al}^{3+}\right.$ in aqueous extract), no significant long-term effect of deforestation and liming was observed.

These results could be used in the management of forested areas endangered by soil acidification. Limestone application can be recommended for younger forests preferentially, where Al toxicity is probable, or for utilization of natural mechanisms in damaged forest recovery.

\section{References}

Adams ML, Davis MR, Powel KJ (2001). Effects of grassland afforestation on exchangeable soil and soil solution aluminium. Australian Journal of Soil Research 39: 1003-1014. - doi: 10.1071/SRo 0054

Augusto L, Ranger J, Binkley D, Rothe A (2002). Impact of several common tree species of European temperate forests on soil fertility. Annals of Forest Science 59: 233-53. - doi: 10.1051/ forest:2002020

Berggren D (1992). Speciation and mobilization of aluminium and cadmium in podzols and cambisols of S. Sweden. Water Air and Soil Pollution 62: 125-156. - doi: 10.1007/BFo0478457

Borg H, Sundbom M (2014). Long-term trends of water chemistry in mountain streams in Sweden - slow recovery from acidification. Biogeosciences 11 (1): 173-184. - doi: 10.5194/bg-11-1732014

Boruvka L, Mládková L, Drábek O (2005). Factors controlling spatial distribution of soil acidification and Al forms in forest soils. Journal of Inorganic Biochemistry 99: 1796-1806. - doi: 10.1016/ j.jinorgbio.2005.06.028

Boruvka L, Mládková L, Penízek V, Drábek O, Vašát R (2007). Forest soil acidification assessment using principal component analysis and geostatistics. Geoderma 140: 374-382. - doi: 10.1016/j.geoderma.2007.04.018

Bradová $M$, Tejnecky $V$, Boruvka L, Nemeček K, Ash C, Sebek O, Svoboda M, Zenáhlíková J, Drábek $O$ (2015). The variations of aluminium species in mountainous forest soils and its implications to soil acidification. Environmental Science and Pollution Research 22: 1667616687. - doi: 10.1007/s11356-015-4855-2

Brady NC, Weil RR (2008). The nature and properties of soils. Pearson Prentice Hall, Saddle River, NJ, USA, pp. 992.

Brandtberg PO, Simonsson M (2003). Aluminum and iron chemistry in the $O$ horizon changed by a shift in tree species composition. Biochemistry 63: 207-228. - doi: 10.1023/A:1023303023 695

Collignon C, Boudot JP, Turpault MP (2012). Time change of aluminium toxicity in the acid bulk soil and rhiyosphere in Norway spruce (Picea abies (L.) Karst.) and (Fagus sylvatica L.) stands. Plant and soil 357: 259-274. - doi: 10.1007/s11104012-1154-2

Descheemaeker K, Muys B, Nyssen J, Sauwens W, Haile M, Poesen J, Raes D, Deckers J (2009). Humus form development during forest restoration in exclosures of the Tigray highlands, Northern Ethiopia. Restoration Ecology 17: 280289. - doi: 10.1111/j.1526-100X.2007.00346.x

De Schrijver A, Geudens G, Augusto L, Staelens J, Mertens J, Wuyts K, Gielis L, Verheyen K (2007). The effect of forest type on throughfall deposition and seepage flux: a review. Oecologia 153 (3): 663-674. - doi: 10.1007/s00442-007-0776-1 Dlouhá S, Boruvka L, Pavlu L, Tejnecky V, Drábek O (2009). Comparison of Al speciation and other soil characteristics between meadow, 
young forest and old forest stands. Journal of Inorganic Biochemistry 103: 1459-1464. - doi: 10.1016/j.jinorgbio.2009.07.024

Drábek O, Boruvka L, Mládková L, Kočárek M (2003). Possible method of aluminium speciation in forest soils. Journal of Inorganic Biochemistry 97 (1): 8-15. - doi: 10.1016/S0162-0134 (03)00259-9

Drábek O, Mládková L, Boruvka L, Száková J, Nikodem A, Nemeček K (2005). Comparison of water-soluble and exchangeable forms of $\mathrm{Al}$ in acid forest soils. Journal of Inorganic Biochemistry 99: 1788-1795. - doi: 10.1016/j.jinorgbio.20 05.06.024

Drábek O, Boruvka L, Pavlu L, Nikodem A, Pírková I, Vacek O (2007). Grass cover on forest clear-cut areas ameliorates soil chemical properties. Journal of Inorganic Biochemistry 101: 1224-1233 - doi: 10.1016/j.jinorgbio.2007.06.011

Exley C (2003). A biogeochemical cycle for aluminium? Journal of Inorganic Biochemistry 97: 1-7. - doi: 10.1016/S0162-0134(03)00274-5

Fritsch E, Allard T, Benedetti MF, Bardy M, Do Nascimento NR, Li Y, Calas G (2009). Organic complexation and translocation of ferric iron in podzols of the Negro River watershed. Separation of secondary Fe species from Al species. Geochimica et Cosmochimica Acta 73: 18131825. - doi: 10.1016/j.gca.2009.01.008

Heese PR (1998). A textbook of soil chemical analysis. John Murray, London, UK, pp. 520.

Huang YM, Kang RH, Ma XX, Qi Y, Mulder J, Duan $L$ (2014). Effects of calcite and magnesite application to a declining Masson pine forest on strongly acidified soil in Southwestern China. Science of the Total Environment 481: 469-478. - doi: 10.1016/j.scitotenv.2014.02.090 Inagaki Y, Miura S, Kohzu A (2004). Effects of forest type and stand age on litterfall quality and soil $\mathrm{N}$ dynamics in Shikoku district, southern Japan. Forest Ecology and Management 202: 107-117. - doi: 10.1016/j.foreco.2004.07.029 IUSS Working Group WRB (2015). World reference base for soil resources 2014 (update 2015). World Soil Resources Reports no. 106, FAO, Rome, Italy, pp. 203.

Jones AM, Collins RN, Waite TD (2011). Mineral species control of aluminum solubility in sulfaterich acidic waters. Geochimica et Cosmochimica Acta 75: 965-77. - doi: 10.1016/j.gca.2010.12. 001

Jones DL, Willett VB (2006). Experimental evaluation of methods to quantify dissolved organic nitrogen (DON) and dissolved organic carbon (DOC) in soil. Soil Biology and Biochemistry 38: 991-999. - doi: 10.1016/j.soilbio.2005.08.012

Kopáček J, Vesely J (2005). Sulfur and nitrogen emissions in the Czech Republic and Slovakia from 1850 till 2000. Atmospheric Environment 39: 2179-2188. - doi: 10.1016/j.atmosenv.2005.01. 002

Lawrence GB, Hazlett PW, Fernandez IJ, Ouimet R, Bailey SW, Shortle WC, Smith KT, Antidormi MR (2015). Declining acid deposition begins reversal of forest-soil acidification in the north- eastern US and eastern Canada. Environmental Science and Technology 49: 13103-13111. - doi: 10.1021/acs.est.5b02904

Li W, Johnson CE (2016). Relationships among $\mathrm{pH}$, aluminum solubility and aluminum complexation with organic matter in acid forest soils of the Northeastern United States. Geoderma 271: 234-242. - doi: 10.1016/j.geoderma.20 16.02.030

Lundström US, Van Breemen N, Bain D (2000). The podzolization processes. A review. Geoderma 94: 91-107. - doi: 10.1016/So016-7061(99) 00036-1

Maitat O, Boudot JP, Merlet D, Rouiller J (2000). Aluminium chemistry in two contrasted acid forest soils and headwater streams impacted by acid deposition, Vosges Mountains, NE France. Water Air and Soil Pollution 117: 217-243. doi: 10.1023/A:1005132321147

Misson L, Ponette Q, André F (2001). Regional scale effects of base cation fertilization on Norway spruce and European beech stands situated on acid brown soils: soil and foliar chemistry. Annals of Forest Science 58: 699-712. - doi: 10.1051/forest:2001157

Mládková L, Boruvka L, Drábek O (2004). Distribution of aluminium among its mobilizable forms in soils of Jizera Mountains region. Plant Soil and Environment 50 (8): 346-351. - doi: 10.17221/4042-PSE

Niemtur S, Mankovska B, Godzik B, Grodzinska $K$, Szaro RC (2002). Changes in Carpathian forest soils caused by air pollution and other factors. In: Proceedings of the NATO Advanced Research Workshop "Effects of Air Pollution on Forests Health and Biodiversity in Forest of the Carpathian Mountains". Stará Lesná (Slovakia) 22-26 May 2001. NATO Science Series 2002, IOS Press Ohmsha, Tokyo, pp. 225-235.

Norton SA, Vesely J (2003). Acidification and acid rain. In: "Environmental Geochemistry, treatise on geochemistry, vol. 9" (Lollar BS ed). Elsevier, Amsetrdam, Netherlands, pp. 367-406. doi: 10.1016/Bo-08-043751-6/09052-6

Pierzynski GM, Sims JT, Vance GF (2000). Soils and environmental quality ( $2^{\text {nd }}$ edn). CRC Press LLC, Boca Raton, FL, USA, pp. 569.

Podlešáková E, Nemeček J, Sirovy $\mathrm{V}$, Lhotsky J, Macurová $\mathrm{H}$, Ivanek $\mathrm{O}$, Bumerl $\mathrm{M}$, Hudcová $\mathrm{O}$, Voplakal K, Hálová G, Blahovec F (1992). Analysis of soils, waters and plants. VúMOP, Prague, Czech Republic, pp. 259. [in Czech]

Pohlman AA, McColl JG (1988). Soluble organics from forest litter and their role in metal dissolution. Soil Science Society of America Journal 52: 265-271. - doi: 10.2136/sssaj1988.0361599500520 $0010047 x$

Ponge JF, André J, Zackrisson O, Bernier N, Nilsson M-C, Gallet C (1998). The forest regeneration puzzle. Bioscience 48: 523-528. - doi: 10.230 7/1313314

Sauer D, Sponagel H, Sommer M, Giani L, Jahn R, Stahr K (2007). Podzol: soil of the year 2007. A review on its genesis, occurrence, and functions. Journal of Plant Nutrition and Soil Sci- ence 170: 581-597. - doi: 10.1002/jpln.200700135 Shaw SA, Hendry MJ (2009). Geochemical and mineralogical impacts of $\mathrm{H}_{2} \mathrm{SO}_{4}$ on clays between pH 5.0 and -3.0. Applied Geochemistry 24: 333-345. - doi: 10.1016/j.apgeochem.2008.10. 011

Sposito G (1996). The environmental chemistry of aluminum. Lewis Publishers, CRC Press LLC, Boca Raton, FL, USA, pp. 480.

Sucharova J, Suchara I, Hola M, Reimann C, Boyd R, Filzmoser P, Englmaier P (2011). Linking chemical elements in forest floor humus (Ohhorizon) in the (zech republic to contamination sources. Environmental Pollution 159: 12051214. - doi: 10.1016/j.envpol.2011.01.041

Tejnecký V, Drábek O, Boruvka L, Nikodem A, Kopáč J, Vokurková P, Sebek O (2010). Seasonal variation of water extractable aluminium forms in acidified forest organic soils under different vegetation cover. Biogeochemistry 101: 151-163doi: 10.1007/s10533-010-9450-5

Trap J, Laval K, Akpa-Vinceslas M, Gangneux C, Decaëns T, Aubert M (2011). Humus macro-morphology and soil microbial community changes along a 130-yr-old Fagus sylvatica chronosequence. Soil Biology and Biochemistry 43 (7): 1553-1562. - doi: 10.1016/j.soilbio.2011.04.005

Tyler G, Olsson T (2001). Concentrations of 60 elements in the soil solution as related to the soil acidity. European Journal of Soil Science 52: 151165. - doi: 10.1046/j.1365-2389.2001.to1-1-00360. $x$

Van Hees PAV, Lundström US, Giesler R (2000). Low molecular weight organic acids and their Al-complexes in soil solution - composition, distribution and seasonal variation in three podzolized soils. Geoderma 94: 173-200. - doi: 10.1016/So016-7061(98)00140-2

Van Hees PAV, Tipping E, Lundström US (2001). Aluminium speciation in forest soil solution modelling the contribution of low molecular weight organic acids. Science of the Total Environment 278: 215-229. - doi: 10.1016/S00489697(01)00653-2

Wesselink GL, Van Breemen N, Mulder J, Janssen PH (1996). A simple model of soil organic matter complexation to predict the solubility of aluminium in acid forest soils. European Journal of Soil Science 47: 373-384. - doi: 10.1111/j.13652389.1996.tbo1411.x

Zeysset M, Blaser P, Luster J, Gehring AU (1999). Aluminum solubility control in different horizons of podzols. Soil Science Society of America Journal 63: 1106-1115. - doi: 10.2136/sssaj199 $9.6351106 x$

\section{Supplementary Material}

Tab. S1 - Distribution of Al fractions among soil horizons.

Tab. S2 - Results of ANOVA multiple range test

Link: Pavlu_2498@supplo01.pdf 